FIU Law Review

Volume 11

Number 2 Separation of Powers

Article 6

Spring 2016

\title{
State Court Judges Are Not Bound by Nonoriginalist Supreme Court Interpretations
}

Lee J. Strang

The University of Toledo College of Law

Follow this and additional works at: https://ecollections.law.fiu.edu/lawreview

Part of the Constitutional Law Commons, and the Courts Commons

Online ISSN: 2643-7759

Recommended Citation

Lee J. Strang, State Court Judges Are Not Bound by Nonoriginalist Supreme Court Interpretations, 11 FIU L. Rev. 327 (2016).

DOI: https://dx.doi.org/10.25148/lawrev.11.2.6

This Article is brought to you for free and open access by eCollections. It has been accepted for inclusion in FIU Law Review by an authorized editor of eCollections. For more information, please contact lisdavis@fiu.edu. 


\title{
State Court Judges Are Not Bound by Nonoriginalist Supreme Court Interpretations
}

\author{
Lee J. Strang*
}

\section{INTRODUCTION}

Federalism is an important structural principle of the United States Constitution. ${ }^{1}$ The existence of the states, and the accompanying federalstate relationship - and tension - are enduring features - not bugs - of our federal system. ${ }^{2}$ Federalism also advances a number of important values, including protection of individual liberty, ${ }^{3}$ jurisdictional experimentation, ${ }^{4}$ and greater satisfaction of the reasonable diversity of different forms of human flourishing. ${ }^{5}$

Most scholarly discussion of and cases concerning federalism have involved state legislatures and executives. These primarily arise in the context of preemption, which was precipitated by creative and broad postNew Deal interpretations of federal power that had, as one effect, the significant displacement of state regulatory authority. ${ }^{6}$ Congress passed statutes that directly regulated private parties or created administrative

John W. Stoepler Professor of Law \& Values, The University of Toledo College of Law. Many thanks to the FIU Law Review and Professor Elizabeth Price Foley for organizing and hosting the Separation of Powers Symposium, and the Symposium participants and audience for their thoughtful comments and suggestions. This Essay represents my tentative thoughts on this subject. Some of my claims need further development to both confirm and fully elucidate them.

1 See Arizona v. United States, 132 S. Ct. 2492, 2500 (2012) ("Federalism, central to the constitutional design, adopts the principle that both the National and State Governments have elements of sovereignty the other is bound to respect.").

2 See Texas v. White, 74 U.S. (7 Wall.) 700, 725 (1868) ("The Constitution, in all its provisions, looks to an indestructible Union, composed of indestructible States."); see also New York v. United States, 505 U.S. 144, 162-63 (1992).

3 See NFIB v. Sebelius, 132 S. Ct. 2566, 2578 (2012) ("The independent power of the States ... serves as a check on the power of the Federal Government .. . [and b]y denying any one government complete jurisdiction over all the concerns of public life, federalism protects the liberty of the individual from arbitrary power.") (quotations omitted).

4 See New State Ice Co. v. Liebmann, 285 U.S. 262, 311 (1932) (Brandeis, J., dissenting) ("It is one of the happy incidents of the federal system that a single courageous state may, if its citizens choose, serve as a laboratory; and try novel social and economic experiments without risk to the rest of the country.").

5 See Gregory v. Ashcroft, 501 U.S. 452, 458 (1991) ("This federalist structure of joint sovereigns preserves to the people numerous advantages. It assures a decentralized government that will be more sensitive to the diverse needs of a heterogeneous society . ...").

6 See United States v. Lopez, 514 U.S. 549, 564 (1995) (“[I]t is difficult to perceive any limitation on federal power, even in areas such as criminal law enforcement or education where States historically have been sovereign."). 
agencies that did so. For example, states traditionally regulated employeremployee relationships via the common law and, with increasing regularity as the twentieth century went on, via statute and regulation. Congress preempted much of the state regulation of private labor relations during the New Deal ${ }^{7}$ in a series of statutes premised on the New Deal Court's broad interpretation of the Commerce Clause ${ }^{8}$ and created an administrative agency to implement the acts. ${ }^{9}$ Scholarship has evaluated the extent to which this form of more-intrusive federal regulation has impacted federalism and whether that impact has been positive or negative.

The role of state courts has received less attention in the federalism literature. This is understandable because the conventional view is that state courts are functionally interpretative adjuncts to the Supreme Court. "The decisions of the Supreme Court of the United States on federal questions are absolutely binding on the state courts and must be followed, regardless of those courts' views. ${ }^{\prime 10}$ However, state courts remain an important facet of federalism. In particular, states and their courts, as independent sovereigns in our federal system, retain independent interpretative authority, and their interpretations may-and, where appropriate, should-diverge from the U.S. Supreme Court's interpretations.

In this Essay, I argue, from an originalist perspective, that state court judges must follow (1) United States Supreme Court judgments and (2) originalist constitutional interpretations found in Supreme Court opinions, but that state courts are not bound by (3) nonoriginalist Supreme Court interpretations of the Constitution. ${ }^{11}$ My claim hinges on two distinctions: (1) between judgments and opinions; and (2) between originalist and nonoriginalist decisions. I show that, because of state court judges' location outside of the Article III hierarchy and their status as independent state sovereigns exercising state judicial power, they possess interpretative independence in the face of nonoriginalist Supreme Court interpretations. At the same time, because of the Article III "judicial Power" exercised by the Supreme Court, and the Supremacy Clause, state court judges must follow Supreme Court judgments and originalist Supreme Court opinions.

This Essay tries to hit the "Goldilocks" zone of state court interpretative autonomy. It provides a space for state courts to contest nonoriginalist U.S. Supreme Court interpretations while, at the same time,

7 Machinists v. Wis. Emp't Rel. Comm'n, 427 U.S. 132 (1976); San Diego Bldg. Trades Council, Millmen's Union, Local 2020 v. Garmon, 359 U.S. 236 (1959).

$8 \quad$ NLRB v. Jones \& Laughlin Steel Corp., 301 U.S. 1 (1937).

9 National Labor Relations Act, 29 U.S.C. $\S 1$ 151-69 (1935).

1021 CORPUS JURIS SECUNDUM, Courts $§ 216$ (2015).

11 In the short space of this Essay, I offer only my tentative thoughts on the extent of state court interpretative independence from nonoriginalist Supreme Court interpretations. 
preserving the Supreme Court's and federal interpretative supremacy. It avoids both the pitfall of federal judicial interpretative supremacy and the pitfall of interpretative anarchy.

\section{ThE STANDARD NARRATIVE: No ROOM FOR FEDERALISM}

The conventional story told by our legal practice and by nonoriginalist scholars is that the Supreme Court is the supreme interpreter of the Constitution. The Supreme Court famously equated its interpretations of the Constitution with the Constitution itself in Cooper v. Aaron. ${ }^{12}$

[Marbury v. Madison] declared the basic principle that the federal judiciary is supreme in the exposition of the law of the Constitution, and that principle has ever since been respected by this Court and the Country as a permanent and indispensable feature of our constitutional system. It follows that the interpretation of the Fourteenth Amendment enunciated by this Court in the Brown case is the supreme law of the land, and Art. VI of the Constitution makes it of binding effect on the States .... ${ }^{13}$

More recently, in Planned Parenthood v. Casey, the Court reaffirmed its grandiose self-conception as the authoritative interpreter. ${ }^{14}$ Professor Daniel Farber summarized the scholarly wisdom when he concluded that "the Court [in Cooper] was largely correct in viewing its constitutional decisions as part of the law of the land."15

The standard narrative provided by the conventional view is that the Supreme Court-building on seeds planted in Marbury v. Madison, ${ }^{16}$ Martin v. Hunter's Lessee, ${ }^{17}$ and Cohens v. Virginia ${ }^{18}$-(finally!) articulated the constitutional rule that it is the "supreme" interpreter of the Constitution in Cooper v. Aaron. In Cooper, the Supreme Court claimed that its constitutional interpretations are binding on all other government officials. ${ }^{19}$

12 Cooper v. Aaron, 358 U.S. 1 (1958).

13 Id. at 18.

14 See Planned Parenthood of Se. Pa. v. Casey, 505 U.S. 833, 866-67 (1992) ("Where, in the performance of its judicial duties, the Court decides a case in such a way as to resolve the sort of intensely divisive controversy reflected in Roe and those rare, comparable cases, its decision has a dimension that the resolution of the normal case does not carry. It is the dimension present whenever the Court's interpretation of the Constitution calls the contending sides of a national controversy to end their national division by accepting a common mandate rooted in the Constitution.").

15 Daniel A. Farber, The Supreme Court and the Rule of Law: Cooper v. Aaron Revisited, 1982 U. ILL. L. REV. 387, 390; see also John Yoo, Judicial Supremacy Has Its Limits, 20 TEX. REV. L. \& PoL. 1,6 (2015) ("[I]t is fair to say that the majority of scholars support judicial supremacy.").

16 Marbury v. Madison, 5 U.S. (1 Cranch) 137 (1803).

17 Martin v. Hunter's Lessee, 14 U.S. (1 Wheat.) 304 (1816).

18 Cohens v. Virginia, 19 U.S. (6 Wheat.) 264 (1821).

19 Cooper v. Aaron, 358 U.S. 1, 17-18 (1958). 
To reach this literally unprecedented conclusion, the Court articulated a syllogism that equated its interpretations of the Constitution with the Constitution itself. ${ }^{20}$

This conventional view offers little-to-no space for federalism to operate in the context of state courts. Indeed, that's the conventional view's whole point. One of the Cooper Court's goals was to eliminate state officer interpretative independence.

The Cooper Court was famously short on justification for its momentous assertion. ${ }^{21}$ As with many other instances where the Warren Court made bold claims with, at best, modest argumentative support, scholars since Cooper have offered different justifications to support Cooper's conclusion. ${ }^{22}$

Originalist scholarship in the area of the authority of Supreme Court decisions, as in many areas, has staked out a different path. Thus far, most originalist scholarship has focused on the relative interpretative authority of the three branches of the federal government. ${ }^{23}$ The consensus of scholars who have investigated this subject is that the Supreme Court's judgments are binding on the other branches,${ }^{24}$ and the Court's constitutional interpretations that justify its judgments and which are contained in its opinions are not authoritative on the other branches. ${ }^{25}$

The scholars who have argued for this interpretative dichotomy made a number of arguments. For instance, these scholars argued that each branch of the federal government must utilize its own, independent interpretative judgment because they must ascertain what the Constitution means when they exercise their respective executive and legislative powers pursuant to their oaths of office. ${ }^{26}$

In this Essay, I build on the interpretative dichotomy identified by these scholars and argue that Cooper was only partially correct. Cooper was right that U.S. Supreme Court judgments are binding on state courts, full stop. The Court was wrong, however, because only its originalist opinions are binding on state courts; the Court's nonoriginalist interpretations are not

20 Id. at 18.

21 Farber, supra note 15, at 388.

22 See, e.g., id. at 390 (arguing that the Supreme Court's constitutional opinions are binding federal common law).

23 E.g., Yoo, supra note 15, at 1; William Baude, The Judgment Power, 96 GEO. L.J. 1807 (2008); Gary Lawson \& Christopher D. Moore, The Executive Power of Constitutional Interpretation, 81 IowA L. REV. 1267 (1996); Michael Stokes Paulsen, The Most Dangerous Branch: Executive Power to Say What the Law Is, 83 GEO. L.J. 217 (1994).

24 The important and powerfully argued exception is Professor Michael Stokes Paulsen. Paulsen, supra note 23 , at 221-22.

25 See sources cited supra note 23.

26 Yoo, supra note 15, at 4-5. 
binding.

III. State Court Judges ARE OUtSide of THE ARTICLE III HiERARChy, Do Not EXERCISE FEDERAL JUdiCIAL POWER, AND ARE THEREFORE NOT BOUND BY THE STARE DECISIS EFFECT OF SUPREME COURT DECISIONS

The United States Supreme Court's opinions and judgments are binding on lower federal courts because of the power lower federal courts exercise and their place in the hierarchical structure of the federal judicial branch. State courts, by contrast, are outside of the federal judicial branch, and outside of the federal government altogether. Therefore, some rationale other than the one applicable to lower federal courts must be identified to justify the authority Supreme Court judgments and opinions possess over state courts, if any.

The default rule of our federal system is that states and their courts are independent sovereigns. ${ }^{27}$ Only to the extent the American People delegated authority to the federal government, and that authority has been properly exercised, are states, their courts, and their citizens, constitutionally limited. ${ }^{28}$ Therefore, one must identify a source of constitutional authority that the U.S. Supreme Court lawfully exercised to direct state courts. Otherwise, state courts retain interpretative independence.

This interpretative independence is, of course, bounded by the state court judges' good faith adherence to their oaths. This is not interpretative anarchy. However, to the extent that one believes that the Constitution's meaning is difficult to access, underdetermined, and that state judges are susceptible to bad faith, then interpretative variations will result from interpretative independence. ${ }^{29}$

Lower federal courts, by contrast, are bound by Supreme Court precedent, and for two related reasons. First, lower federal courts must follow Supreme Court precedent because they exercise "judicial Power." Second, lower federal courts are bound by Supreme Court precedent because of their status as "inferior" to the Supreme Court.

The federal judicial branch operates as a branch, with the members of the branch working together, in different capacities. The Constitution

27 NFIB v. Sebelius, 132 S. Ct. 2566, 2602 (2012); see also Texas v. White, 74 U.S. (7 Wall.) 700,725 (1868) ("The Constitution, in all its provisions, looks to an indestructible Union, composed of indestructible States.”).

28 U.S. Const. amend. X; id. art. VI, cl. 2; see M'Culloch v. Maryland, 17 U.S. (4 Wheat.) 316, 405 (1819) ("If any one proposition could command the universal assent of mankind, we might expect it would be this - that the government of the Union, though limited in its powers, is supreme within its sphere of action.").

29 Though, the evidence suggests that state courts already exercise significant interpretative autonomy. Jason Mazzone, When the Supreme Court Is Not Supreme, 104 NW. U.L. REV. 979 (2010). 
established the Supreme Court ${ }^{30}$ and structured the federal court system, ${ }^{31}$ should Congress create lower federal courts, ${ }^{32}$ which it did in the 1789 Judiciary Act. ${ }^{33}$ All federal judges within the Article III hierarchy exercise the same "judicial Power." ${ }^{34}$ This power includes the requirement that federal judges give federal court precedent "significant respect." ${ }^{35}$ How federal judges up and down the hierarchy afford the constitutionallyrequired significant respect varies. For Supreme Court justices, the Court's own originalist precedent must be followed unless there is significant evidence that the precedent did not correctly articulate or apply the Constitution's original meaning. ${ }^{36}$ Supreme Court justices should overrule nonoriginalist precedent, unless doing so would gravely harm the common good. ${ }^{37}$

For lower federal court judges, their obligation is different because their position is "inferior." 38 Lower federal court judges must faithfully follow higher court precedent, regardless of its status as originalist or nonoriginalist. This is partially because of stare decisis. Stare decisis, as I noted, mandates that lower federal judges give Supreme Court precedent significant respect.

However, there are other facets of lower federal court practice that stare decisis by itself fails to capture. In particular, lower federal court judges give both originalist and nonoriginalist precedent stare decisis respect, and the level of stare decisis respect is greater than significant respect. These modifications to the lower federal court practice of precedent is explained by the Article III hierarchy that makes lower federal courts "inferior" to the Supreme Court. ${ }^{39}$ Like "inferior" ${ }^{40}$ executive branch officers, who are answerable to higher-level officers including the President, ${ }^{41}$ lower federal court judges must follow higher court precedent, even if the lower federal court judges correctly believe it is incorrect. The

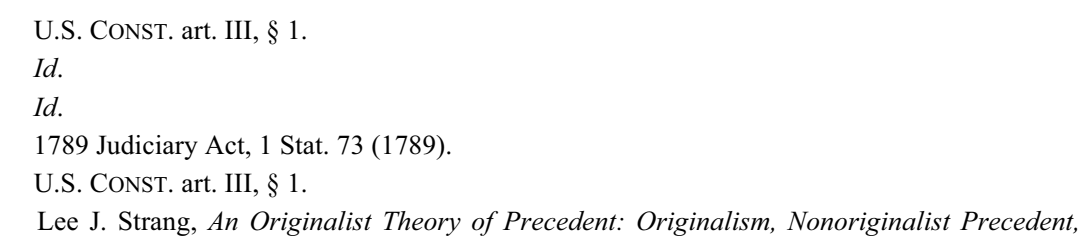

36 Lee J. Strang, An Originalist Theory of Precedent: The Privileged Place of Originalist Precedent, 2010 BYU L. ReV. 1729, 1751 (2010).

37 Strang, supra note 35 , at 420.

38 U.S. CONST. art. III, $\S 1$.

39 Id.

$40 \quad$ Id. art. II, § 2, cl. 2 .

41 See Myers v. United States, 272 U.S. 52, 117-37 (1926) (explaining the Decision of 1789); Saikrishna Prakash, New Light on the Decision of 1789, 91 CoRNELL L. REV. 1021 (2006) (supporting Myers' interpretation of the Decision). 
practice of lower court judges following higher court precedent is relatively uncontroversial. $^{42}$

The reasons why lower federal courts are bound by Supreme Court precedent do not apply to state courts. First, state courts do not exercise federal judicial power, and hence are not obligated to give Supreme Court precedent stare decisis respect. Second, state courts are not within the federal judicial branch and therefore are not inferior courts to the Supreme Court.

State courts and state judges are not part of the federal judicial branch. Therefore, state court judges do not exercise "judicial Power." They exercise the power conferred on them by their respective state constitutions. For example, the Ohio Constitution delegated to the Ohio judicial branch the "judicial power" of Ohio, not any federal power. ${ }^{43}$ In fact, our legal system's conception of national popular sovereignty precludes the possibility of one state's people granting federal power to that state's courts. ${ }^{44}$ The different power exercised by state courts means that they are not subject to a constitutional obligation from Article III to give Supreme Court precedent any respect, much less significant respect. Instead, state court judges exercise whatever power they received from their state constitutions and the citizens of their states.

The power state court judges exercise does not-at least not necessarily-require them to give federal court precedent (or any precedent, for that matter ${ }^{45}$ ) respect. ${ }^{46}$ State judges may have to do so, as a matter of their state constitutions' meaning, but that is a contingent matter. ${ }^{47}$ Andthough I have not investigated this to a significant degree-it is unlikely that the original meaning of state judicial power includes respect for federal court precedent. ${ }^{48}$

42 See Gary Lawson, The Constitutional Case Against Precedent, 17 HARV. J.L. \& PUB. POL'Y 23, 23-24 (1994) ("The authority of precedent is a postulate of our legal system. It is uncontroversial.").

43 OHIO CONST. art. IV, $\S 1$.

44 See M'Culloch v. Maryland, 17 U.S. (4 Wheat.) 316, 403-04 (1819) ("The government proceeds directly from the people; is 'ordained and established,' in the name of the people; and is declared to be ordained, 'in order to form a more perfect union, establish justice, insure domestic tranquility, and secure the blessings of liberty to themselves and to their posterity."').

45 See Mary Garvy Algero, Considering Precedent in Louisiana: Balancing the Value of Predictable and Certain Interpretation with the Tradition of Flexibility and Adaptability, 58 LoY. L. REV. 113 (2012) (describing Louisiana's evolution away from the civil law's traditional lack of stare decisis toward some respect for past precedents).

46 See Amanda Frost, Inferiority Complex: Should State Courts Follow Lower Federal Court Precedent on the Meaning of Federal Law?, 68 VAND. L. REV. 53, 62 (2015) (describing the various approaches state courts take to the precedential weight, if any, of federal court precedent).

47 Id.

48 This is prima facie unlikely for a number of reasons. For example, state judicial power in some states could not include the obligation to follow federal court precedent because those states' constitutions were created prior to the federal court system. Additionally, a state's people's grant of state 
Second, state court judges are not within the federal branch hierarchy, and therefore are not "inferior" to the federal courts, including the Supreme Court, within the meaning of Article III. Instead, state courts are part of their own state court hierarchies. Article III describes only those courts "ordain[ed] and establish[ed]" by Congress as inferior courts in the federal judicial hierarchy. ${ }^{49}$ Congress, of course, did not create state courts.

Furthermore, Article III would require state court judges to hold their offices with Article III tenure and salary protections, ${ }^{50}$ which is not the case. A powerful piece of evidence confirming this interpretation is that lower federal courts have no appellate jurisdiction over state courts, even those within the federal courts' geographic jurisdiction. ${ }^{51}$

Article III also lacks the sort of express statement of Supreme Court supervisory authority over the various state court systems that would make it clear that the state courts are inferior components of one federal court system. This possibly reflected "doubts about the power of the Supreme Court to exercise general powers of superintendence over the state court system." 52

Article III does make state courts subject to the U.S. Supreme Court's appellate jurisdiction, but this does not convert them into Article III inferior courts. ${ }^{53}$ Appellate jurisdiction is the power to "revise and correct" an action initiated in another court. ${ }^{54}$ It may apply to a court within the same judicial system as the appellate court, but logically and historically, that need not be the case. Chief Justice Marshall relied on this distinction in Cohens v. Virginia to rebut Virginia's Eleventh Amendment argument that the U.S. Supreme Court could not hear an appeal from a criminal case initiated in its courts. ${ }^{55}$

judicial power to the state's courts would not include deference to federal court precedent because the state's people were establishing and empowering a separate court system empowered by a separate sovereign.

49 U.S. CONST. art. III, $\S 1$.

50 Id. ("The Judges, both of the supreme and inferior Courts, shall hold their Offices during good Behaviour, and shall, at stated Times, receive for their Services, a Compensation, which shall not be diminished during their Continuance in Office.").

51 See Frost, supra note 46, at 55 ("Lower federal court precedent cannot bind state courts, or so we are told.").

52 James E. Pfander, Jurisdiction Stripping and the Supreme Court's Power to Supervise Inferior Tribunals, 78 TEX. L. REV. 1433, 1457 (2000).

53 See James E. Pfander, Federal Supremacy, State Court Inferiority, and the Constitutionality of Jurisdiction-Stripping Legislation, 101 NW. U.L. REV. 191, 228-29 (2007) (arguing that Article III's grant of appellate jurisdiction to the Supreme Court over state courts does not, by itself, adequately support a state court duty to follow Supreme Court precedent).

54 Marbury v. Madison, 5 U.S. (1 Cranch) 137, 175 (1803) ("It is the essential criterion of appellate jurisdiction, that it revises and corrects the proceedings in a cause already instituted, and does not create that cause.").

55 Cohens v. Virginia, 19 U.S. (6 Wheat.) 264, 398 (1821) (arguing that the Eleventh 
My description of the relationship between state courts and the U.S. Supreme Court is supported by the Supreme Court's refusal, until very recently, to issue extraordinary writs to state courts. Extraordinary writs include discretionary writs, like mandamus. Superior courts utilized these extraordinary writs to maintain supremacy over and control of inferior courts. ${ }^{56}$ The Supreme Court issued these writs to lower federal courts since the Republic's beginning to maintain its supremacy over them. By contrast, the first clear instance where the Supreme Court issued an extraordinary writ to a state court was not until $1978,{ }^{57}$ and even then, the Supreme Court did not explain the source of its authority to do so. ${ }^{58}$ The Supreme Court's failure to issue extraordinary writs to state courts until recently, and its failure to provide an explanation when it did so, shows that state courts are constitutionally not inferior courts.

A potentially powerful counter-argument to my position is that state courts, to the extent they adjudicate federal questions, are "constitute[d]" federal tribunals by Congress under Article I, Section 8, Clause $7 .^{59}$ These tribunals are "inferior to the supreme Court" and therefore are subject to the precedential weight of the Supreme Court's cases. ${ }^{60}$ Article I tribunals created by Congress, such as military and territorial courts, fall within the scope of this Clause. Though I have not yet fully investigated this question, if Congress designated some or all state courts as federal courts, then it is likely those courts would have been "constitute[d]" by Congress and therefore "inferior" to the Supreme Court. However, even if that was theoretically possible, Congress has not done so. Instead, from the Republic's beginning, Congress created a system of lower federal courts, and state courts, utilizing their own state judicial power, have also entertained federal claims from the Constitution's initiation. ${ }^{61}$ State courts would do so in the context of suits and prosecutions brought within their own state-defined scope of jurisdiction. For example, the Maryland state court entertained an action for debt against the Baltimore branch of the Second Bank of the United States, and within that suit, the Bank's cashier raised a federal constitutional defense. ${ }^{62}$ Absent a theory of implied

Amendment may bar the Supreme Court from hearing a case in its original jurisdiction while not barring an appeal from such a case initially heard in state court).

56 Pfander, supra note 53, at 212-14.

57 See Gen. Atomic Co. v. Felter, 436 U.S. 493, 497 (1978).

58 Pfander, supra note 53, at 230-31.

59 U.S. ConST. art. I, § 8, cl. 7; see Pfander, supra note 53, at 229-32 (making this argument).

60 See Pfander, supra note 52; see also Pfander, supra note 53.

61 Within their state-conferred jurisdiction, state courts have adjudicated federal claims pursuant to the Supremacy Clause's command that state judges treat federal law as law of the state and to privilege it over contrary state law.

62 M'Culloch v. Maryland, 17 U.S. (4 Wheat.) 316, 317 (1819). 
"constitut[ing]" by Congress, which is implausible, Article I, Section 8 , Clause 7 is not a source of state court constitutional inferiority.

Furthermore, even if state courts were "inferior" to the Supreme Court in a manner identical to lower federal courts, state courts exercise state judicial power and not federal judicial power. Federal judicial power includes the obligation to give the Supreme Court's precedent "significant respect." Whether the state judicial power exercised by the state courts includes a similar requirement is contingent on the meaning of judicial power in each state. To my knowledge, there is no evidence on that question, and there are strong reasons to believe that state judicial power does not mean giving Supreme Court precedent stare decisis weight. For example, some of the state courts predated the creation of the U.S. Supreme Court, so the judicial power exercised by these state courts could not include giving respect to Supreme Court precedent. ${ }^{63}$

In sum, the reasons why lower federal courts must follow Supreme Court precedent do not apply to state courts. Below, I argue that state courts must follow originalist Supreme Court decisions, and Supreme Court judgments.

\section{State Court Judges ARe Bound by \\ ORIGINALIST SUPREME COURT DECISIONS AND NOT BOUND BY NONORIGINALIST SUPREME COURT DECISIONS}

In this Part, I argue that state courts' duty to follow U.S. Supreme Court decisions $^{64}$ hinges on whether those decisions are originalist or nonoriginalist. A reminder that my argument assumes that originalism is the correct theory of interpretation. State court judges must follow originalist decisions, but not nonoriginalist decisions. Next, in Part V, I argue that, when subject to an otherwise-applicable nonoriginalist decision, state court judges must still follow the U.S. Supreme Court's judgments in those precedents.

State court judges are bound by originalist Supreme Court decisions because those decisions are correct interpretations of the Constitution. In this originalist precedent, the Supreme Court articulates the Constitution's meaning as fixed at its point of ratification and applies that meaning to the

63 Even if these state constitutions were amended following adoption of the current Constitution and establishment of the federal Supreme Court, the point remains that it was not necessary for state judicial power to include respect for Supreme Court precedent.

64 Here, in Part IV, I use the label "decision" to describe the subject of analysis at a relatively high level of generality and to elide the distinction between a court's judgment and its opinion. As I describe in Part V, a decision typically includes both a judgment and an opinion. I also use "decision" as synonymous with "precedent," but I use the label decision here and reserve the label precedent for the context of a decision's stare decisis effect, if any. 
facts of the case. ${ }^{65}$ This conclusion is the uncontroversial ${ }^{66}$ application of originalism's fixation and contribution theses. ${ }^{67}$ State judges take an oath ${ }^{68}$ to "support" the Constitution's original meaning, and are "bound" by it. ${ }^{69}$ State court judges' obligation is analogous to the duty of other state and federal officers because of the constitutionally prescribed oath they take. ${ }^{70}$ For example, even if a state supreme court believed that robust gun control was more appropriate public policy than individual gun rights, it must still follow District of Columbia v. Heller's ${ }^{71}$ originalist interpretation of the Second Amendment. ${ }^{72}$

Another way to get to this same conclusion is to think of what reasonable reasons ${ }^{73}$ a state supreme court could give that would justify its refusal to follow an originalist U.S. Supreme Court decision. By hypothesis, the Supreme Court decision in question correctly articulated and applied the Constitution's authoritative meaning. The state supreme court has before it an analogous case and should reach the same conclusion in its case. By hypothesis, the state supreme court could not refuse to follow the U.S. Supreme Court precedent because the precedent failed to faithfully articulate the Constitution's original meaning, nor could it reject the U.S. Supreme Court precedent for its failure to correctly apply that meaning. State court judges' oath therefore compels them to follow originalist U.S. Supreme Court decisions. For instance, the U.S. Supreme Court's Crawford v. Washington ${ }^{74}$ decision is originalist - it correctly articulated and applied the Constitution's original meaning — so a state supreme court has no reason not to follow it.

65 Strang, supra note 36, at 1739-51.

66 Uncontroversial within originalism.

67 Lawrence B. Solum, The Fixation Thesis: The Role of Historical Fact in Original Meaning, 91 Notre DAME L. REV. 1, 1 (2015).

68 For an extended argument on the ethical responsibilities of officials who swear oaths, see STEVE SHEPPARD, I Do SOLEMNLy SWEAR: THE MORAL OBLIGATIONS OF LEGAL OfFICIALS (2009).

69 See Lee J. Strang, Originalism's Subject Matter: Why the Declaration of Independence Is Not Part of the Constitution, 89 S. CAL. L. REV (forthcoming 2016) (arguing that officer oath-taking binds these officers to the written Constitution); Christopher R. Green, "This Constitution": Constitutional Indexicals as a Basis for Textualist Semi-Originalism, 84 NOTRE DAME L. REV. 1607 (2009) (arguing that the Constitution's indexicals, when coupled with the Constitution's chronological identification, officer oath-taking, and the Supremacy Clause, supports originalism). But see Richard M. Re, Promising the Constitution, 110 NW. U.L. REV. 299, 322 (2016) ("Promissory constitutionalism suggests that issues of methodology largely turn on the empirical question of how the public understands 'the Constitution."').

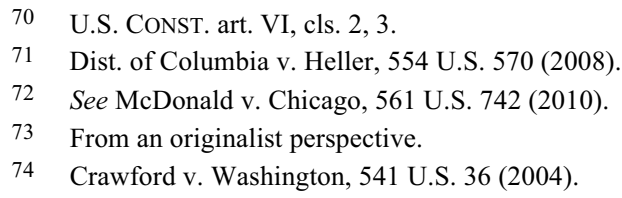


By contrast, state court judges are not bound by nonoriginalist Supreme Court decisions because those decisions are incorrect interpretations or applications of the Constitution. This too is the relatively uncontroversial application of originalism's fixation and contribution theses. Nonoriginalist precedent departs from the Constitution's fixed original meaning. The Constitution requires state court judges to take an oath to "support" the Constitution ${ }^{75}$ which binds them to the Constitution's original meaning. ${ }^{76}$ A Supreme Court decision's status as a nonoriginalist precedent would prevent it from being "in Pursuance" of the Constitution. ${ }^{77}$ A U.S. Supreme Court decision that is unfaithful to the Constitution's original meaning not only does not bind state court judges; the judges' oath compels them to not follow it. ${ }^{78}$ If a state court judge followed the nonoriginalist decision, that judge would not be "support[ing]" the Constitution; he would be undermining it. Nor would the judge be "bound" by the Constitution if he followed the nonoriginalist decision.

Originalism in Good Faith (OIGF) is the standard to determine whether a decision is originalist or nonoriginalist. I explained OIGF in prior work. $^{79}$ The OIGF standard requires that a decision evince an objective good faith effort to articulate and apply the Constitution's original meaning. ${ }^{80}$ This evidence is gathered from the decision itself. ${ }^{81}$ For instance, if the opinion evaluated the pertinent historical evidence bearing on a question of original meaning, then that is a (not-determinative) reason to treat the decision as originalist. A decision is originalist if it meets the OIGF standard; a precedent is nonoriginalist if it fails to meet the OIGF standard. $^{82}$

If a decision meets the OIGF standard-if it is an originalist precedent - it is protected by a rebuttable presumption. ${ }^{83}$ This rebuttable presumption means that other courts should give the decision respect, unless a party overcomes the presumption by showing that there is no substantial evidence that the decision is, in fact, originalist. ${ }^{84}$

A nonoriginalist decision, by contrast, is owed no respect. Such decisions either incorrectly articulated or incorrectly applied the Constitution's original meaning. Instead, as I described above, because it is

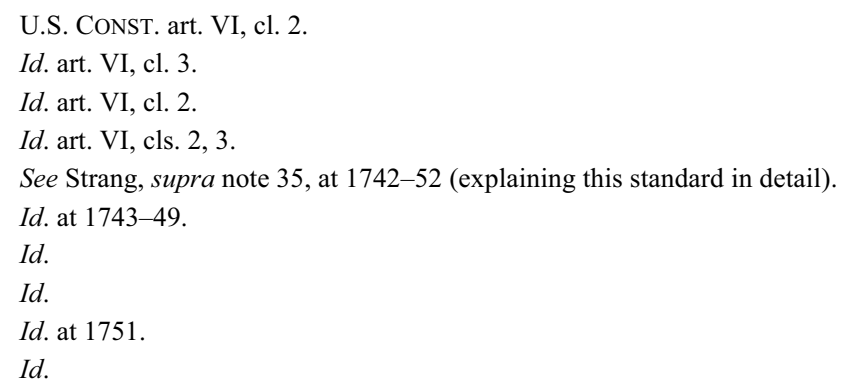


an incorrect constitutional interpretation, state court judges have a duty to reject the decision.

\section{STATE Court Judges ARE BOUnd BY SUPREME COURT JUDGMENTS, NOT OPINIONS}

Here, I argue that U.S. Supreme Court judgments are binding on state court judges. State court judges' obligation to follow Supreme Court judgments exists regardless of the accuracy of the interpretations supporting the judgments. In other words, the judgment of a nonoriginalist precedent binds state courts just as much as a judgment in an originalist precedent.

Judicial decisions today typically have two basic components: a judgment and an opinion. ${ }^{85}$ The judgment is the legal determination of liability among the parties to a case. ${ }^{86}$ It awards or denies the relief claimed by the plaintiff(s) from the defendant(s) in the case. In Fairfax's Devisee $v$. Hunter's Lessee, for instance, the Supreme Court reviewed a decision of the Court of Appeals of Virginia involving the meaning of a treaty. ${ }^{87}$ The Supreme Court reviewed the Virginia court's decision via a writ of error, which was the common law mechanism to review a lower court's judgment. ${ }^{88}$ The Supreme Court's decision explained why the Jay Treaty required reversal, ${ }^{89}$ and then issued its mandate to the Court of Appeals of Virginia ordering it to enter judgment for Martin. ${ }^{90}$ The Supreme Court's mandate only required a change of the Court of Appeals of Virginia's judgment; it did not mandate that it agree with the Supreme Court's legal reasoning.

85 See Wright \& Miller, Federal Practice And Procedure $§ 2651$ ("The decision consists of the court's findings of fact and conclusions of law; the rendition of judgment is the pronouncement of that decision and the act that gives it legal effect."); Yoo, supra note 15, at 6. Of course, it is not always the case today, and it was more frequently not the case early in the Republic, that Supreme Court decisions possessed both opinions and judgments. Today, the Supreme Court disposes of some of its cases without an opinion. The early Supreme Court utilized seriatim opinions delivered by the different justices.

86 WRIGHT \& MILLER, supra note 85, § 2651.

87 Fairfax's Devisee v. Hunter's Lessee, 11 U.S. (7 Cranch) 603 (1812).

88 See 5 CORPUS JURIS SECUNDUM, Appeal and Error $\S 842$ (describing the writ of error).

89 Fairfax's Devisee, 11 U.S. at 627.

90 See Hunter v. Martin, 18 Va. (4 Munf.) 1, 2 (1814) (quoting the U.S. Supreme Court's mandate: "the judgment of the Court of Appeals in and for the Commonwealth of Virginia, in this case be, and the same is hereby reversed and annulled, and that the judgment of the District Court of Winchester be affirmed, with costs; and it is further ordered, that the said cause be remanded to the said Court of Appeals in and for the Commonwealth of Virginia, with instructions to enter judgment for the appellant, Philip Martin - and the same is hereby remanded accordingly.-You therefore are hereby commanded that such proceedings be had in said cause, as according to right and justice, and the laws of the United States, and agreeably to said judgment and instructions of said Supreme Court ought to be had, the said writ of error notwithstanding."). 
The opinion explains and justifies the judgment in a case. ${ }^{91}$ The opinion ascertains the Constitution's meaning, evaluates the parties' arguments, and explains which party's arguments are correct. The opinion then describes why the Constitution requires the judgment. For example, in Martin v. Hunter's Lessee, the Supreme Court reversed the Court of Appeals of Virginia's judgment. ${ }^{92}$ Justice Story explained, in the Court's opinion, why Article III's grant of appellate jurisdiction to the Supreme Court authorized the 1789 Judiciary Act Section 25's grant of jurisdiction to the Supreme Court to review state court judgments. ${ }^{93}$

The core or focal case of the "judicial Power" exercised by the Supreme Court (and other federal courts) is its authority to issue final judgments. ${ }^{94}$ These judgments are binding on the parties to the case, and officials who have sworn an oath to support the Constitution must follow and enforce these judgments. ${ }^{95}$ This is true even if the judgment rests on an incorrect opinion: even if the Supreme Court incorrectly interpreted the Constitution. ${ }^{96}$ Therefore, the other branches of the federal government and state officers must enforce Supreme Court judgments, even if they believe that a judgment is insufficiently justified. ${ }^{97}$

Scholars have offered a host of arguments to support this claim, and this appears to be the consensus position. These arguments utilize various facets of the Constitution's text and structure, the historical background of English and American practice, the Framing and Ratification debates, and early practice under the Constitution. For example, Professor William Baude relied on Article III's text and the principle of coordinate branches, among many other reasons. He argued that, since Article III "judicial Power" operated on (only) cases and controversies, this power culminated in the form of judgments. So long as these judgments were within the scope of the federal courts' jurisdiction — so long as they were within an Article

91 See Wright \& MILlER, supra note 85, § 2651 ("The decision consists of the court's findings of fact and conclusions of law; the rendition of judgment is the pronouncement of that decision and the act that gives it legal effect.").

92 Martin v. Hunter's Lessee, 14 U.S. (1 Wheat.) 304 (1816).

93 Id.

94 Plaut v. Spendthrift Farm, 514 U.S. 211 (1995); Baude, supra note 23.

95 Yoo, supra note 15, at 6.

96 Baude, supra note 23, at 1809; Yoo, supra note 15, at 7.

97 Professor Paulsen has powerfully argued that the President possesses "the Merryman power" to refuse to follow both Supreme Court opinions and judgments. See Michael Stokes Paulsen, The Merryman Power and the Dilemma of Autonomous Executive Branch Interpretation, 15 CARDOZO L. REV. 81 (1993); Paulsen, supra note 23. In this Essay, I do not finally commit to a position on Professor Paulsen's claims. Most of Professor Paulsen's claims apply to the federal and not state governments. If Professor Paulsen is correct, and if his claims are applicable to state courts, then both U.S. Supreme Court opinions and judgments are not binding, and my narrower claim that state courts are not bound by U.S. Supreme Court judgments remains correct. 
III case or controversy - they were authoritative, in a manner similar to the authority of a congressional statute passed within the scope of its jurisdiction, its Article I powers. ${ }^{98}$

My own (very tentative) view is that Supreme Court judgments are binding on state courts because of a combination of Articles I, III, and VI. The Supremacy Clause requires that state court judges privilege only those "Laws" made "in Pursuance" of the Constitution. "There are two steps that must occur in order for a U.S. Supreme Court action to actualize a state court judge's Supremacy Clause obligation to follow it; for the judge to be "bound" by a Supreme Court judgment. First, the federal legal norm must be a "Law." Second, it must be "in Pursuance" of the Constitution.

Congress, exercising its Necessary and Proper Clause authority " $[t] \mathrm{o}$ make all Laws which shall be necessary and proper for carrying into Execution ... all other Powers vested by this Constitution... in any Department or Officer" ${ }^{\prime 100}$ and to execute Article III, passed the Judiciary Act of $1789 .^{101}$ Section 25 of the Act authorized the Supreme Court to review state court "judgments" via the common law writ of error. ${ }^{102}$ This is a "Law" within the Supremacy Clause's meaning, ${ }^{103}$ and it is undisputed that Section 25 was constitutional. ${ }^{104}$

When the Supreme Court reversed a state court's judgment before the Court via its appellate jurisdiction, within the scope of and to effectuate its Article III "judicial Power," and pursuant to Section 25, that exercise of power is privileged by the Supremacy Clause. The Supremacy Clause ordered a state court that received a U.S. Supreme Court mandate to reverse its judgment and follow the Supreme Court's mandate over its own prior state court judgment. This same analysis holds true for the current constitutional and statutory authorization of Supreme Court review of state court judgments. ${ }^{105}$

By contrast, Supreme Court opinions are not binding on other federal branches or state officials. ${ }^{106}$ Article III and statutory authorization to

98 Baude, supra note 23, at 1832-33.

99 U.S. CONST. art. VI.

100 U.S. CONST. art. I, § 8, cl. 18.

101 An Act to Establish the Judicial Courts of the United States, 1 Stat. 73 (1789).

102 Id. $\S 25$.

103 See Pfander, supra note 53, at 228 (rejecting the claim that the Supreme Court's precedents, by themselves, are encompassed by the Supremacy Clause).

104 See WRIGHT \& MILLER, supra note 85, § 4006 ("These successive statutory provisions rest on an unassailable constitutional foundation.").

10528 U.S.C. $\S 1257$ (a); see also WRIGHT \& MiLLER, supra note 85, § 4006 (explaining the evolution of the Supreme Court's authority to review state court judgments and current law).

106 See Baude, supra note 23, at 1810 ("[The Supreme Court] has no power to tell other people not before the court what they should do.") (emphasis omitted). Within the federal judicial branch, federal judges must give both judgments and opinions significant respect because of their status as 
review state court decisions extends only to the U.S. Supreme Court's judgments, not its opinions. The articulation of the Court's reasons for its judgment are not necessary to effectuate the exercise of its Article III power and beyond its statutory authority, both of which privilege only judgments. There is therefore no "Law" "in Pursuance" of the Constitution upon which the Supremacy Clause may operate.

The Supreme Court's opinions' force rests entirely on their ability to persuade that they embody correct interpretations of the Constitution. In fact, until John Marshall became Chief Justice, there were no opinions of the Court, only the seriatim opinions of the various justices. It was therefore impossible for the Court's interpretative reasoning to bind other government officers because it did not exist, unless a majority of the justices in their seriatim opinions agreed on the same interpretative reasoning, which was unlikely.

In sum, state court judges must follow U.S. Supreme Court judgments in all cases within the Court's case or controversy and appellate jurisdiction, and authorized by (constitutional) federal statute. This duty applies even when the interpretative reasons supporting the judgments are nonoriginalist.

\section{CANONICAL ARguments SupPorting Judicial REVIEW Show That State COURT Judges ARE Not BOUND BY NONORIGINALIST SUPREME COURT OPINIONS}

In this Part, I bring together the claims made in Parts IV and V and couple them with canonical arguments used to justify judicial review. I argue that state court judges are not bound by nonoriginalist Supreme Court opinions because of the confluence of two related characteristics. First, if a Supreme Court decision is an incorrect nonoriginalist interpretation of the Constitution, its warrant as an interpretation of the Constitution fails. Second, since the authoritativeness of a Supreme Court's opinion is dependent on its accuracy, then a nonoriginalist opinion lacks authority.

The arguments utilized by Alexander Hamilton in Federalist No. $78,{ }^{107}$ and Chief Justice Marshall in Marbury v. Madison, ${ }^{108}$ support state judge interpretative independence when faced with nonoriginalist Supreme Court opinions. First, both Hamilton and Marshall relied on the separation of powers to argue that the status of the Supreme Court as coordinate with the other federal branches supported the exercise of judicial review. Each

\footnotetext{
"inferior" members of the branch. The Supreme Court's opinions facilitate its supervision of the lower federal courts.

107 The FedERALIST No. 78 (Alexander Hamilton).

108 Marbury v. Madison, 5 U.S. (1 Cranch) 137 (1803).
} 
branch of the federal government, they argued, would exercise its powers independently - separately - from the others. When Congress legislated, for example, it would necessarily interpret the Constitution to determine whether it had the authority to pass an act and whether the act complied with constitutional limitations. Similarly, the Supreme Court would necessarily determine the Constitution's meaning in (some of) its cases. Each branch, they argued, was coordinate so that no single branch's constitutional interpretations were controlling on the others. If it was otherwise, then that would mean that one branch's interpretations were preeminent, which conflicted with the bedrock structural principle of branch coordinancy.

This same argument justifies state judge interpretative independence from nonoriginalist Supreme Court opinions. Unlike in Marbury, the bedrock constitutional principle at work in this context is federalism. Federalism is the principle that the federal and state governments are supreme in their respective spheres of authority and that each may not regulate in the other's sphere.

The Supreme Court and the respective state supreme courts are coordinate courts, within their respective spheres. The Supreme Court's opinions are binding on state courts when it acts within its sphere of Supremacy Clause authority, which is when its opinions meet the Originalism in Good Faith standard. Similarly, when the Supreme Court's opinions are nonoriginalist, they are not supreme over state judges, and state judges exercise coordinate interpretative authority.

Chief Justice Marshall also argued that, because federal judges swore an oath to support the Constitution, ${ }^{109}$ they must utilize their own interpretative judgment when exercising the judicial power. ${ }^{110}$ This meant that federal judges must make their own good faith judgments on the Constitution's meaning and cannot blindly follow to Congress' or the President's interpretations of the Constitution.

This same argument supports state judge interpretative independence from Supreme Court nonoriginalist interpretations. Article VI expressly enjoins state court judges to "support" the Constitution. In the exercise of their state judicial power, state judges must make good faith judgments on the Constitution's meaning. They cannot unthinkingly follow the Supreme Court's interpretations of the Constitution. The Constitution's text makes this corollary patent because it treats federal and state judges identically: "judicial Officers, both of the United States and of the several States"111 must take the oath.

\footnotetext{
109 U.S. CONST. art. VI, cl. 2.

110 Marbury, 5 U.S. at 180.

111 U.S. CONST. art. VI, cl. 2.
} 


\section{STATE COURT JUdGE INTERPRETATIVE INDEPENDENCE FROM NONORIGINALIST SUPREME COURT OPINIONS ADVANCES THE VALUES OF FEDERALISM}

The Supreme Court and scholars have identified three primary benefits from the federal structure of the United States. First, the most frequently identified value of federalism is that it protects individual liberty, and through two primary mechanisms. The first mechanism is dividing power among different governments. Vertically dividing power among governments prevents the concentration of power, which is a necessary precondition to the suppression of liberty. Relatedly, dividing power among different governments also provides mechanisms to check governmental power. ${ }^{112}$ One government can check another government by active or passive resistance to its exercises of power and, in doing so, protect individual liberty. ${ }^{113}$

The second mechanism is creating jurisdictional competition for the affections of people. Humans value liberty so, when governments compete for citizens and their affections, one of the axes upon which they compete is liberty. The states and federal governments compete to offer regulatory "packages" that contain the most liberty.

Second, the Supreme Court and scholars argue that federalism creates space for jurisdictional experimentation. In a unitary state, there is only one jurisdiction and only that government can experiment with different approaches to subject matters. Experimentation presents significant risk because the entire jurisdiction suffers if the experiment fails. And that assumes that experimentation will occur, which is more difficult in unitary states because of the difficulty garnering a sufficient consensus to experiment.

Federalism both increases the likelihood of experimentation and reduces the risks posed by it. It is more likely that experimentation will occur in a federal system because one state is more likely than the entire nation to have a consensus to experiment because of the uneven distribution of preferences. Furthermore, if an experiment fails to provide net benefits, the experiment's costs are limited to that one state, and the other jurisdictions in fact benefit from that state's failed experiment by not duplicating it.

112 For example, the federal government does not possess an enumerated power over education so that, at least until very recently, states were the primary directors of American education policy, which helped states form young Americans in distinct and healthy ways.

113 For instance, many northern states passively and actively resisted repatriation of purported slaves to the South pursuant to the original and 1850 Fugitive Slave Acts. 
Currently, some states are experimenting with alternative approaches to drugs. Some states are relaxing restrictions on drug use. These states had a sufficient consensus to engage in this experiment. Since the jury is still out on whether these experiments are beneficial, any costs from this experiment are internalized by the experimenting states, and the other states in the Union will benefit from both the experimenting states' successes and failures.

Third, federalism provides a greater variety of environments in which the reasonable diversity of forms of human flourishing can find a home. Human beings flourish through a nearly infinite variety of combinations of the basic human goods. ${ }^{114}$ Some humans, for example, value the good of knowledge relatively more than others, while other people value friendship more than other goods, etc. This same reasonable diversity of approaches to human flourishing occurs on the state level.

States in a federal system have the capacity to construct reasonably different "packages" of background services that cater to different avenues of human flourishing. For instance, a state may reasonably choose to regulate its citizens' lives, or one facet of life, more or less than another state. Iowa regulates farm activity less than California because these states reasonably balance the costs and benefits of farming and its impact on other facets of life differently. Iowa, for example, prioritizes family farming over other business structures for agriculture production.

State court interpretative autonomy from nonoriginalist Supreme Court opinions advances federalism's values. Of course, it is difficult to measure a priori how this autonomy will advance federalism. My arguments supporting this claim are tentative and do not offer a full analysis of the issue. Nevertheless, for each of these three federalism values-liberty, experimentation, and diverse human flourishing — current practice identifies examples of state court interpretative autonomy advancing them.

First, state interpretative autonomy currently exists where states can interpret their state constitutions to provide "greater"115 protection to individual rights than the U.S. Supreme Court's interpretations of the federal Constitution. ${ }^{116}$ This has occurred, for instance, in some states following the Supreme Court's rulings that the Free Speech Clause did not protect free speech activities in privately owned shopping centers. ${ }^{117}$ California's Supreme Court interpreted the California Constitution's free

114 See JOHN FINNIS, NATURAL LAW AND NATURAL RIGHTS 90 (1980).

115 I put "greater" in quotes because it is not always clear whether the different protection afforded through state constitutional interpretation results in a net increase in liberty.

116 William J. Brennan, Jr., States Constitutions and the Protection of Individual Rights, 90 HARV. L. REV. 489 (1977).

117 Lloyd Corp. v. Tanner, 407 U.S. 551 (1972). 
speech clause to provide protection of speech on privately owned shopping malls. ${ }^{118}$ The California Supreme Court's interpretative independence rejected the federal interpretation so that, within California, greater freedom of speech prevailed.

Second, existing state interpretative autonomy has led to experimentation. The U.S. Supreme Court has interpreted the Takings Clause to permit government taking of private property and transferring it to another private party to obtain the public benefit generated by increased economic activity from the new use(s) for the property. ${ }^{119}$ Both before and after Kelo, state courts interpreted their state constitutions to provide a different and greater level of protection for property owners. For instance, in City of Norwood v. Horney, the Ohio Supreme Court expressly rejected the federal path and ruled that the Ohio Constitution's takings clause prohibited such takings. ${ }^{120}$ The interpretative independence exercised by states like Ohio is providing a series of experiments regarding which interpretation(s) provide the most net benefit.

Third, existing state interpretative autonomy has provided space for the reasonable diversity of human life to find a home. One area where humans have reasonably diverged is the extent to which the law should protect religious beliefs and religiously motivated actions from legal regulation when that regulation is not targeted at religion. Religion is a basic human good the exploration of which adds to human flourishing. However, the fact that religion is valuable does not, by itself, determine the extent to which religiously inspired activity should be shielded from government regulation. The U.S. Supreme Court famously ruled that the Free Exercise Clause did not protect religiously motivated activity from neutral government regulation, that is regulation not targeted at the religiously motivated activity. ${ }^{121}$ That is a reasonable, ${ }^{122}$ though not (at least at the time) a popular approach. ${ }^{123}$ State supreme courts prior to and after Smith utilized their interpretative independence to provide more robust protection to religiously motivated activity. For instance, the Ohio Supreme

$\begin{array}{ll}118 & \text { Robins v. Pruneyard Shopping Ctr., } 592 \text { P.2d } 341 \text { (Cal. 1979). } \\ 119 & \text { Kelo v. City of New London, } 545 \text { U.S. } 469 \text { (2005). } \\ 120 & \text { City of Norwood v. Horney, } 853 \text { N.E. } 2 \text { d } 353 \text { (Ohio 2006). } \\ 121 & \text { Emp't Div., Dep't of Nat'l Res. v. Smith, } 494 \text { U.S. } 872 \text { (199). }\end{array}$

122 See Gerard v. Bradley, Beguiled: Free Exercise Exemptions and the Siren Song of Liberalism, 20 HOFSTRA L. REV. 245 (1991) (supporting Smith).

123 Michael W. McConnell, Accommodation of Religion: An Update and a Response to the Critics, 60 GEO. WASH. L. REV. 685 (1992) (reviewing arguments concerning constitutional religious exemptions); Michael W. McConnell, Exchange; Religious Participation in Public Programs: Religious Freedom at a Crossroads, 59 U. CHI. L. REV. 115 (1992) (arguing that the religion clauses should be read together to promote religious freedom); Michael W. McConnell, Free Exercise Revisionism and the Smith Decision, 57 U. CHI. L. REV. 1109 (1990) (criticizing Smith as both historically and philosophically wrong). 
Court rejected Smith and ruled that the Ohio Constitution's free exercise clause provided greater protection to religiously motivated activity. ${ }^{124}$

In sum, state court interpretative autonomy from nonoriginalist Supreme Court opinions provides space for federalism to operate and state supreme courts may utilize this autonomy in a way that advances federalism's values.

\section{My ARgument For STATE COURT JUdGE INTERPRETATIVE INDEPENDENCE FROM NONORIGINALIST SUPREME COURT OPINIONS IS MODEST}

The first reaction that many scholars have to the proposal that state courts should have modest interpretative independence is negative. They associate state court interpretative independence with segregationist resistance to Brown, ${ }^{125}$ which culminated in Cooper v. Aaron. ${ }^{126}$ More recently, scholars have expressed distress at the fleeting and modest rumblings in some quarters that Obergefell $v$. Hodges ${ }^{127}$ incorrectly interpreted the Constitution. There are real and powerful reasons to avoid significant state court interpretative independence. However, this Essay's prescription for interpretative independence is modest.

This modest state court interpretative independence from nonoriginalist Supreme Court opinions fits most of American historical legal practice. Throughout American history, federal and state officers have frequently contested U.S. Supreme Court interpretations, but they have nearly always followed the Court's judgments. For instance, even though President Lincoln disagreed with the Supreme Court's constitutional interpretation in Dred Scott v. Sanford, ${ }^{128}$ he argued that the Court's judgment was binding.

My prescription is modest because, as a practical matter, the U.S. Supreme Court possesses the authority to eventually force state courts to follow its nonoriginalist interpretations, if it has the political will to do so. This would occur when a state supreme court's judgments contrary to the U.S. Supreme Court's nonoriginalist interpretations are repeatedly reviewed by the U.S. Supreme Court and repeatedly reversed. This process is certainly more time-consuming than state courts simply falling into line upon the Supreme Court's initial utterance of a constitutional interpretation. But, the practical result is ultimately the same: The U.S. Supreme Court's

\footnotetext{
124 Humphrey v. Lane, 728 N.E. 2 d 1039 (Ohio 2000).

125 Brown v. Bd. of Educ., 347 U.S. 483 (1954).

126 Cooper v. Aaron, 358 U.S. 1 (1958).

127 Obergefell v. Hodges, 135 S. Ct. 2584 (2015).

128 Dred Scott v. Sandford, 60 U.S. (19 How.) 393 (1857).
} 
nonoriginalist interpretation is and remains the governing law within the state, despite the state supreme court's disagreement.

This end result of my argument for modest state court interpretative autonomy in the face of U.S. Supreme Court nonoriginalist interpretations might cause one to ask: so what's the point? The difference is that, with the arguments I presented, the U.S. Supreme Court may still be able to force state supreme courts to follow its nonoriginalist interpretations, but it has to utilize significant political capital over an extended period of time to do so.

Let me point to an historical example that exemplifies this: the saga of Ableman v. Booth. ${ }^{129}$ Ableman is one case in a long series of episodes of northern state resistance to the 1850 Fugitive Slave Act. The Wisconsin Supreme Court repeatedly rejected the U.S. Supreme Court's constitutional interpretation that justified the Act. The U.S. Supreme Court, under Chief Justice Taney, repeatedly reversed the Wisconsin Supreme Court. Even after the U.S. Supreme Court's rulings, Wisconsin continued to resist the Act. In Ableman, the U.S. Supreme Court was able to enforce its constitutional interpretation, but only at the cost of resources and political capital expended repeatedly checking and reversing the Wisconsin Supreme Court. This resistance by the Wisconsin Supreme Court provided a very public statement of a different constitutional interpretation, a period of practical resistance to the U.S. Supreme Court's interpretation, and a focal point for opposition to the U.S. Supreme Court's interpretation.

My modest prescription preserves the U.S. Supreme Court's and federal interpretative supremacy while, at the same time, preserving a space for states to articulate a different constitutional interpretation that may-or may not-over time, provide an opportunity for other government officers to cooperate, reject, or push back against U.S. Supreme Court nonoriginalist interpretations.

\section{CONCLUSION}

In this brief Essay, I provided a tentative argument for modest state court interpretative independence. I argued that state courts possess interpretative independence from nonoriginalist U.S. Supreme Court interpretations. I also argued that state courts must follow all Supreme Court judgments and originalist Supreme Court opinions. I closed by suggesting that this modest state court interpretative independence is likely to advance federalism's three primary values. 